\title{
ANALISIS PROTEIN PADA TEPUNG KECAMBAH KACANG HIJAU (Phaseolus aureus L.) YANG DIKECAMBAHKAN MENGGUNAKAN MEDIA AIR, AIR CUCIAN BERAS DAN AIR KELAPA
}

\author{
Dirga $^{1}$, Nurisyah Asyhari ${ }^{2}$, Agust Dwi Djayanti ${ }^{2}$. \\ ${ }^{1}$ Program Studi Farmasi, Fakultas Sains, Institut Teknologi Sumatera, Lampung, Indonesia \\ ${ }^{2}$ Program Studi Farmasi, Fakultas Farmasi, Politeknik Kesehatan Makassar, Makassar Indonesia
}

\begin{abstract}
:
Nuts have long been known as a complementary source of protein with whole grains, such as rice and wheat. One of the many types of nuts that widely available are green beans. Utilization of waste such as coconut water and rice washing water as an additional substance of the plant fertilizer needs to be improved given the high levels of nutrients that can be beneficial to the plant. This study aims to analyze the protein in wheat sprouts green beans (Phaseolus aureus L.) that germinated using the Water, Rice Washing Water and Coconut Water. Wheat sprouts green beans were analyzed qualitatively with the ninhydrin test, Millon test, and biuret test, then quantitatively analyzed by the Kjeldahl method included the destruction process, distillation and titration. The results showed that protein content of wheat sprouts for wheat germination using water $28,50 \% \mathrm{w} / \mathrm{w}$, protein content in wheat germination using washed rice water $31,19 \% \mathrm{w} / \mathrm{w}$, and protein content in wheat germination using coconut water $32,06 \%$ $w / w$. The highest protein contained in wheat germ on the germination use coconut water $32,06 \% \mathrm{w} / \mathrm{w}$.
\end{abstract}

Keyword: Protein, Wheat Sprouts Green Beans, Water, Rice Washing Water, Coconut Water.

\section{Pendahuluan}

Protein merupakan makromolekul yang paling berlimpah di dalam sel hidup dan merupakan 50 persen atau lebih dari berat kering sel. Protein ditemukan di dalam semua sel dan semua bagian sel. Protein juga amat bervariasi, ratusan jenis yang berbeda dapat ditemukan dalam satu sel.[11] Protein terdiri atas rantai-rantai panjang asam amino, yang terikat satu sama lain dalam ikatan peptida. Asam amino terdiri atas unsur-unsur karbon, hidrogen, oksigen dan nitrogen. Beberapa protein mengandung gugus kimia lain disamping asam amino yaitu unsur-unsur fosfor, besi, sulfur, iodium dan kobalt. Unsur nitrogen adalah unsur utama protein, karena terdapat di dalam semua protein akan tetapi tidak terdapat di dalam karbohidrat dan lemak. Unsur nitrogen merupakan 16\% dari berat protein [2].

Kacang-kacangan telah lama dikenal sebagai sumber protein yang saling melengkapi dengan bijibijian, seperti beras dan gandum. Komoditas ini juga ternyata potensial sebagai sumber zat gizi lain selain protein, yaitu mineral, vitamin B, karbohidrat kompleks dan serat makanan. Di Indonesia, terdapat berbagai jenis kacang-kacangan dengan berbagai warna, bentuk, ukuran dan varietas, yang berpotensi untuk menambah zat gizi dalam diet atau menu sehari-hari. Dimana salah satu diantaranya adalah kacang hijau. [10].

Kacang hijau (Phaseolus Aureus L.) merupakan salah satu komoditas tanaman kacang-kacangan yang banyak dikonsumsi rakyat Indonesia, seperti: bubur kacang hijau, bahan kue dan lain-lain. Tanaman ini mengandung zat gizi, antara lain: amilum, protein, besi, belerang, kalsium, minyak lemak, mangan, magnesium, niasin, vitamin (B1, A, dan E) [1]. Manfaat lain dari tanaman ini adalah sebagai peluruh air seni, melawan disentri, melenyapkan biang keringat, menghilangkan bisul, menyuburkan rambut, menguatkan imunitas tubuh, menyehatkan tulang, menurunkan kolesterol, melancarkan pencernaan, mengurangi resiko kanker, sumber protein nabati, mengendalikan berat badan, mengurangi resiko anemia, mencegah tekanan darah tinggi, menyehatkan otak, keluhan pascamenopause, diabetes, bermanfaat untuk Ibu Hamil dan Menyusui, dan mencegah penyakit jantung [12].

Kandungan gizi kacang hijau cukup tinggi dan komposisinya lengkap, yakni Kalori 345,00 kal, protein 22,00 gram, lemak 1,20 gram, karbihidrat 62,90 gram, kalsium 125,00 gram, fosfor 320,00 mg, vitamin 
A $157,00 \mathrm{SI}$, vitamin B1 0,64 mg, vitamin C 6,00 mg, air 10gram [15]. Berdasarkan berat kering, protein kecambah kacang hijau meningkat menjadi $119 \%$ dibandingkan dengan kandungan awal pada biji Kacang hijau yaitu mengandung protein sebanyak $24 \%$. Hal ini disebabkan terjadinya sintesa protein selama germinasi. Hasil penelitian KAISI, lembaga penelitian kesehatan tubuh manusia di korea, menunjukkan bahwa tiap $100 \mathrm{~g}$ kecambah kacang hijau mengandung 4,2 g protein, 3,4 g karbohidrat, $1,0 \mathrm{~g}$ lemak, $4,7 \mathrm{~g}$ kalori, 9,2 $\mathrm{g}$ air dan $15 \mathrm{~g}$ vitamin $\mathrm{C}$ [4]. Selain itu berdasarkan penelitian yang telah dilakukan, menunjukkan bahwa kadar protein tertinggi tepung kecambah kacang hijau terdapat pada perkecambahan selama 48 jam dalam media air yaitu sebesar $27,69 \%$ b/b [13].

Tepung kacang hijau merupakan salah satu tepung yang bebas gluten yang berasal dari biji kacang hijau. Astawannn. Pengolahan kacang hijau sangat berfariatif mulai dari makanan ataupun minuman, bahkan dapat digunakan sebagai bahan obat - obatan. Hal ini dikarenakan tepung kacang hijau mengandung gizi yang baik untuk pertumbuhan, baik protein, lemak, maupun asam amino. [12]

Dalam kehidupan sehari-hari sering sekali kita temukan dibeberapa tempat terutama di pasar tradisional bahwa limbah air kelapa masih jarang dimanfaatkan, hal ini sangat disayangkan mengingat banyaknya manfaat dalam air kelapa tersebut [2]. Air kelapa mengandung dua hormon alami yaitu auksin dan sitokinin yang dapat bermanfaat sebagai hormon pertumbuhan pada anaman [15]. Begitu pula dengan air cucian beras, masyarakat pada umumnya selalu mengabaikan air hasil cucian beras, dimana air cucian beras mengandung asam lemak, vitamin-vitamin, mangan, fosfor, zat besi yang penting bagi pertumbuhan tanaman [4].

Berdasarkan banyaknya kandungan nutrisi dari air kelapa dan air cucian beras serta mengingat potensi gizi kecambah kacang hijau yang cukup besar, tetapi daya tahan simpannya sangat rendah sehingga perlu upaya alternatif untuk memperbesar daya gunanya. Salah satu cara yang dapat dilakukan adalah dengan cara pembuatan tepung kecambah [4]. Maka dari uraian tersebut muncul suatu permasalahan yakni bagaimana pengaruh kandungan protein pada tepung kecambah kacang hijau (Phaseolus aureus L.) yang dikecambahkan menggunakan media air, air cucian beras dan air kelapa

\section{Metode Penelitian}

\subsection{Jenis penelitian dan desain penelitian:}

Jenis penelitian yang digunakan adalah penelitian eksperimen laboratorium dengan cara melakukan penentuan protein dalam sampel yang dikecambahkan pada media yang berbeda dengan metode kedjhal.

\subsection{Sampel penelitian}

Sampel penelitian yang digunakan dalam penelitian ini adalah kacang hijau (Phaseolus aureus L.) varietas golden green yang diperoleh di Daerah Malakaji Kecamatan Tompobulu Kabupaten Gowa propinsi Sulawesi Selatan yang selanjutnya dikecambahkan menggunakan media air, air cucian beras dan air kelapa kemudian dibuat tepung kecambah.

\subsection{Alat dan bahan yang digunakan}

2.3.1 Alat-alat yang digunakan ayakan, blender, buret, corong, Erlenmeyer, gelas piala, gelas ukur, labu ukur, neraca analitik, oven, penangas air, pipet volum, alat destilasi, alat destruksi.

2.3.2 Bahan yang digunakan adalah Air limbah cucian beras. Air limbah kelapa, Air suling, Asam borat p.a, Asam sulfat $\left(\mathrm{H}_{2} \mathrm{SO}_{4}\right)$ 0,05 N, Asam Sulfat $\left(\mathrm{H}_{2} \mathrm{SO}_{4}\right)$ p.a, Biji Kacang Hijau (Phaseolus aureus $L$.) varietas Golden green, Indikator Bromkresol green, Indikator Fenolftalein, Natrium hidroksida $(\mathrm{NaOH})$ p.a, Natrium Karbonat $\left(\mathrm{Na}_{2} \mathrm{CO}_{3}\right)$ p.a, Nynhydrin, Raksa (II) Nitrat $\mathrm{Hg}\left(\mathrm{NO}_{3}\right)_{2}$, Selenium (Sn), Tembaga (II) sulfat $\left(\mathrm{CuSO}_{4}\right)$.

\subsection{Metode analisis}




\subsubsection{Pengambilan sampel}

Sampel biji kacang hijau (Phaseolus aureus L.) yang digunakan dalam penelitian ini diperoleh dari Daerah Malakaji Kecamatan Tompobulu Kabupaten Gowa Propinsi Sulawesi Selatan. Pengambilan sampel dilakukan dengan menggunakan teknik random sampling dimana sampel diambil secara acak pada suatu wilayah yang dianggap homogen.

\subsubsection{Pengambilan media}

Media yang digunakan dalam penelitian ini yaitu air, limbah air cucian beras, serta limbah air kelapa yang diambil di tempat pengolahan kelapa yang terdapat di salah satu Pasar Tradisional Di Kota Makassar Propinsi Sulawesi Selatan.

\subsubsection{Pembuatan tepung kacang Hijau}

Untuk pembuatan kecambah, dilakukan dengan cara, kacang hijau ditimbang sebanyak 250 gram, lalu direndam dalam $250 \mathrm{ml}$ air, selama 12 jam. Kemudian ditiriskan lalu ditebarkan pada wadah yang berlubang-lubang (nyiru) dan ditutupi kain. Setiap 6 jam sekali disemprot dengan air menggunakan hand sprayer, perkecambahan dilakukan selama 48 jam. Kecambah yang dihasilkan, dikeringkan dalam oven pada suhu $45^{\circ} \mathrm{C}$ sampai diperoleh derajat kekeringan. Kemudian kecambah kacang hijau kering dilepas kulitnya, digiling, dan diayak menjadi tepung. Dengan cara yang sama dilakukan untuk proses perkecambahan dengan menggunakan media limbah air cucian beras dan limbah air kelapa.

\subsubsection{Analisis Kualitatif}

Ditimbang $100 \mathrm{mg}$ serbuk sampel. Masukkan ke dalam erlenmeyer $250 \mathrm{ml}$, Kemudian tambahkan $50 \mathrm{ml}$ aquadest kedalam Erlenmeyer dan kocok, kemudian panaskan dan saring sampel. Larutan hasil penyaringan selanjutnya dilakukan pengujian.

\section{a. Uji Ninhydrin}

Dibuat larutan sampel $2 \%$ dalam aquadest. Ambil $1 \mathrm{~mL}$ sampel tambahkan $1 \mathrm{~mL}$ pereaksi ninhidrin, kemudian panaskan sampai mendidih. Reaksi positif terbentuknya warna biru [5].

\section{b. Reaksi Biuret}

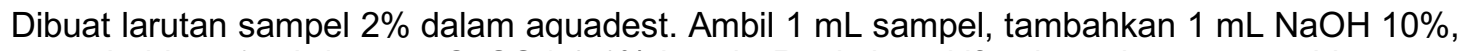
kemudian tambahkan $1 \mathrm{~mL}$ larutan CuSO4 0,1\% kocok. Reaksi positif terbentuknya warna biru ungu [8].

\section{c. Reaksi Millon}

Dibuat larutan sampel $2 \%$ dalam aquadest. Ambil $1 \mathrm{ml}$ sampel tambahkan 5 tetes larutan $\mathrm{Hg}\left(\mathrm{NO}_{3}\right)_{2} 0,1 \mathrm{~N}$, kemudian panaskan sampai mendidih. Reaksi positif terbentuknya endapan merah [8].

\subsubsection{Analisis Kuantitatif}

Penentuan kadar protein dilakukan dengan menggunakan metode Kjeldahl, metode Kjeldahl terdiri dari 3 tahap yaitu: tahap destruksi, tahap destilasi dan tahap titrasi.

a. Analisis Kandungan Nitrogen total dengan Metode Kjeldahl.

Ditimbang 1 gram sampel, masukkan ke dalam labu Kjeldahl $100 \mathrm{ml}$, kemudian pipet $10 \mathrm{mll} \mathrm{H}_{2} \mathrm{SO}_{4}$ pekat masukkan kedalam labu Kjehdahl. Tambahkan katalisator 1 gram selenium untuk mempercepat destruksi. Kemudian labu kjehdahl tersebut di panaskan dimulai dengan api yang kecil setelah beberapa saat sedikit demi sedikit api dibesarkan sehingga suhu menjadi naik. Destruksi dapat dihentikan pada saat didapatkan larutan berwarna jernih kehijauan. Hasil destruksi yang didapatkan kemudian didinginkan, setelah itu diencerkan dengan aquadest sebanyak $200 \mathrm{ml}$. Setelah homogen dan dingin dipipet sebanyak $5 \mathrm{ml}$, masukkan ke dalam labu destilasi. Tambahkan $10 \mathrm{ml} \mathrm{NaOH}$ p.a hingga larutan menjadi basa yang ditandai dengan perubahan warna larutan menjadi ungu. Labu destilat dipasang dan dihubungkan dengan kondensor, lalu ujung kondensor dibenamkan dalam cairan penampung. Uap dari cairan yang mendidih akan mengalir melalui kondensor menuju Erlenmeyer penampung yang berisi $20 \mathrm{ml}$ larutan $\mathrm{H}_{3} \mathrm{BO}_{3} 2 \%$. Hasil destilat dipipet sebanyak 100,0 ml lalu ditambahkan indikator Bromkresol Green sebanyak 3 tetes lalu dititrasi dengan larutan baku $\mathrm{H}_{2} \mathrm{SO}_{4}$ 0,046 N. Titik akhir titrasi ditandai dengan perubahan warna larutan dari hijau menjadi ungu. Dilakukan titrasi blanko dengan perlakuan yang sama tanpa menggunakan sampel

b. Analisis kandungan Nitrogen bukan protein dengan Metode Kjeldahl 
Ditimbang 1 gram sampel, masukkan ke dalam labu destilasi dan ditambahkan $200 \mathrm{ml}$ air suling dan $10 \mathrm{ml} \mathrm{NaOH}$ p.a sampai larutan menjadi basa yang ditandai dengan perubahan warna larutan menjadi ungu. Destilat ditampung dalam Erlenmeyer yang berisi $20 \mathrm{ml}$ larutan $\mathrm{H}_{3} \mathrm{BO}_{3} 2 \%$. Hasil destilasi ditambahkan dengan indikator bromkresol green sebanyak 3 tetes lalu dititrasi dengan larutan baku $\mathrm{H}_{2} \mathrm{SO}_{4} 0,046 \mathrm{~N}$. Titik akhir titrasi ditandai dengan perubahan warna dari hijau menjadi ungu. Labu destilat dipasang dan dihubungkan dengan kondensor, lalu ujung kondensor dibenamkan dalam cairan penampung. Uap dari cairan yang mendidih akan mengalir melalui kondensor menuju Erlenmeyer penampung yang berisi 20 ml larutan $\mathrm{H}_{3} \mathrm{BO}_{3} \%$. Hasil destilat dipipet sebanyak $100,0 \mathrm{ml}$ lalu ditambahkan indikator Bromkresol Green sebanyak 3 tetes lalu dititrasi dengan larutan baku $\mathrm{H}_{2} \mathrm{SO}_{4}$ 0,046 N. Titik akhir titrasi ditandai dengan perubahan warna larutan dari hijau menjadi ungu. Dilakukan titrasi blanko dengan perlakuan yang sama tanpa menggunakan sampel [7] [16].

\subsection{Analisis Data}

Data kadar protein pada tepung kecambah kacang hijau diperoleh melalui nilai kadar nitrogen total dan kadar nitrogen bukan protein yang ditunjukan melalui persamaan dibawah ini, yaitu:

$$
\text { Kadar N Total }(\%)=\frac{v s-v b}{\text { Berat Sampel }(m g)} \times \mathrm{N} \mathrm{H}_{2} \mathrm{SO}_{4} \times 14,008 \times 100 \%
$$

$$
\text { Kadar N bukan protein (\%) }=\frac{V s-V b}{\text { Berat Sampel }(\mathrm{mg})} \times \mathrm{N} \mathrm{H}_{2} \mathrm{SO}_{4} \times 14,008 \times 100 \%
$$

$$
\text { Kadar Protein }=(\text { Kadar N Total }- \text { Kadar N bukan protein }) \times \text { Fk }
$$

Keterangan :

$$
\begin{array}{ll}
\mathrm{Vs} & =\text { Volume titrasi sampel }(\mathrm{ml}) \\
\mathrm{Vb} & =\text { Volume titrasi blanko }(\mathrm{ml}) \\
\mathrm{N} & =\text { Normalitas } \mathrm{H}_{2} \mathrm{SO}_{4} \\
\mathrm{Fk} & =\text { Faktor konversi kacang hijau }=6,25
\end{array}
$$

\section{Hasil dan pembahasan}

\subsection{Hasil Analisis Kualitatif}

Hasil analisis kualitatif protein dalam tepung kecambah kacang hijau menggunakan pereaksi ninhydrin, pereaksi millon, pereaksi biuret menghasilkan hasil yang positif. Hasil analisis dapat dilihat pada tabel dibawah ini :

\begin{tabular}{|c|c|c|c|c|c|}
\hline No & Sampel & Uji & \multicolumn{2}{|c|}{ Warna } & \multirow{2}{*}{ Hasil } \\
\cline { 4 - 5 } & & & Pustaka & Diperoleh & \\
\hline 1. & Tepung A & Ninhydrin & Ungu Biru & Ungu Biru & + \\
& & Millon & Merah & Merah & + \\
& & Biuret & Ungu & Ungu Tua & + \\
\hline 2. & Tepung B & Ninhydrin & Ungu Biru & Ungu Biru & + \\
& & Millon & Merah & Merah & + \\
& & Biuret & Ungu & Ungu Tua & + \\
\hline 3. & Tepung C & Ninhydrin & Ungu Biru & Ungu Biru & + \\
& & Millon & Merah & Merah & + \\
& & Biuret & Ungu & Ungu & + \\
\hline
\end{tabular}

Tabel 1. Hasil Analisis Kualitatif Kandungan Protein Dalam Tepung Kecambah Kacang Hijau

Keterangan tabel: 
$+\quad=$ Mengandung protein

- $\quad$ = Tidak Mengandung Protein

\subsection{Hasil Analisis Kuantitatif}

Hasil analisis kuantitatif protein dalam tepung kecambah kacang hijau dapat dilihat pada tabel dibawah ini :

\begin{tabular}{|c|c|c|c|c|c|}
\hline \multirow[b]{2}{*}{ No } & \multirow[b]{2}{*}{ Sampel } & \multicolumn{2}{|c|}{ Kandungan Nitrogen } & \multirow{2}{*}{$\begin{array}{l}\text { Kadar } \\
\text { Protein } \\
(\mathrm{g} / 100 \mathrm{~g})\end{array}$} & \multirow{2}{*}{$\begin{array}{c}\text { Kadar } \\
\text { Protein } \\
\text { Rata-rata } \\
(\mathrm{g} / 100 \mathrm{~g})\end{array}$} \\
\hline & & $\begin{array}{c}\text { Nitrogen Total } \\
(\% \mathrm{~b} / \mathrm{b})\end{array}$ & $\begin{array}{l}\text { Nitrogen Non } \\
\text { Protein }(\% b / b)\end{array}$ & & \\
\hline 1. & Tepung A & $\begin{array}{l}4,69 \\
4,70 \\
4,66 \\
\end{array}$ & $\begin{array}{l}0,13 \\
0,12 \\
0,12 \\
\end{array}$ & $\begin{array}{l}28,50 \\
28,63 \\
28,38 \\
\end{array}$ & 28,50 \\
\hline 2. & Tepung B & $\begin{array}{l}5,23 \\
5,25 \\
5,21\end{array}$ & $\begin{array}{l}0,24 \\
0,23 \\
0,25\end{array}$ & $\begin{array}{l}31,19 \\
31,38 \\
31,00\end{array}$ & 31,19 \\
\hline 3. & Tepung C & $\begin{array}{l}5,25 \\
5,28 \\
5,23\end{array}$ & $\begin{array}{l}0,12 \\
0,12 \\
0,13\end{array}$ & $\begin{array}{l}32,06 \\
32,25 \\
31,88\end{array}$ & 32,06 \\
\hline
\end{tabular}

Tabel 2. Hasil Perhitungan Kadar Protein Dalam Tepung Kecambah Kacang Hijau

Keterangan Tabel :

Tepung $A$ = Tepung yang dikecambahkan dengan menggunakan Air

Tepung $B=$ Tepung yang dikecambahkan dengan menggunakan Air Cucian Beras

Tepung $\mathrm{C}=$ Tepung yang dikecambahkan dengan menggunakan Air Kelapa

\subsection{Pembahasan}

Penelitian ini dilakukan untuk mengetahui kadar protein pada tepung kecambah Kacang Hijau (Phaseolus aureus L.) yang dikecambahkan menggunakan media air, air cucian beras dan air kelapa. Proses analisis kadar protein dalam tepung kecambah kacang hijau dilakukan dengan dua metode yaitu analisis kualitatif untuk mengetahui ada tidaknya kandungan protein dalam tepung kecambah kacang hijau dan analisis kuantitatif dilakukan untuk mengetahui besarnya kadar protein dalam sampel.

Analisis kandungan protein total terdiri dari 3 tahap yaitu tahap destruksi, destilasi dan titrasi. Pada tahap destruksi protein dipecah menjadi unsur-unsur $\mathrm{C}, \mathrm{H}$, dan $\mathrm{O}$ yang kemudian hilang karena mengalami oksidasi sehingga tersisa unsur nitrogen yang bereaksi dengan $\mathrm{H}_{2} \mathrm{SO}_{4}$ membentuk ammonium sulfat. Pada Tahap destilasi, ammonium sulfat dipecah menjadi ammonium hidroksida $\left(\mathrm{NH}_{4} \mathrm{OH}\right)$ dengan penambahan $\mathrm{NaOH}$ sampai alkalis dan dipanaskan. Karena pengaruh panas yang terdapat pada alat destilasi, maka $\mathrm{NH}_{4} \mathrm{OH}$ akan terurai menjadi gas $\mathrm{NH}_{3}$ dan $\mathrm{H}_{2} \mathrm{O}$. Ammonia yang dibebaskan selanjutnya akan ditangkap oleh larutan asam standar. Asam standar yang dipakai adalah asam borat $2 \%$ dan indikator yang digunakan adalah Bromkresol Green (BCG) agar kontak antara senyawa asam dan ammonia lebih baik. Titrasi menggunakan asam sulfat 0,042 N, titik akhir titrasi ditandai dengan perubahan warna larutan dari hijau menjadi ungu [7].

Kadar protein yang diperoleh merupakan pengurangan dari hasil analisis kandungan nitrogen total dengan nitrogen bukan protein lalu dikalikan dengan faktor konversi kacang hijau yaitu 6,25. Dari hasil analisis kualitatif yaitu melalui uji ninhydrin, uji millon, dan uji biuret diperoleh hasil yaitu ketiga tepung kecambah kacang hijau positif mengandung protein, hal ini ditandai dengan terbentuknya warna ungu biru (Ninhydrin) Merah (Millon) dan warna Ungu (Biuret), dimana warna tersebut terbentuk karna adanya reaksi yang terbentuk antara masing-masing pereaksi dengan protein pada tepung kecambah seperti yang terlihat pada tabel 1 . Sedangkan Pada analisis kuantitatif protein dengan menggunakan metode Kjeldahl menunjukkan bahwa tepung kecambah kacang hijau dengan kandungan kadar protein tertinggi yaitu perkecambahan menggunakan media air kelapa 32,06\%, media air cucian beras 31,19 dan media air $28,5 \%$. Perbedaan nilai kadar protein dari ke tiga jenis tepung tersebut dapat di lihat pada gambar diagram yang tertera pada Gambar 1. 


\title{
Kadar Protein Rata-rata (g/100 g)
}

\author{
- Air Kelapa Air Cucian beras $\quad$ Air
}

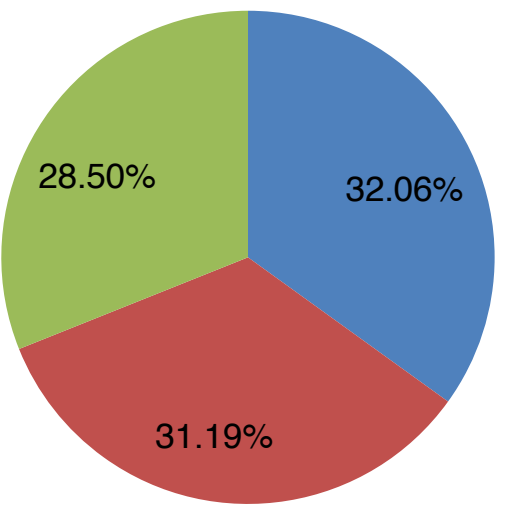

\section{Gambar 1. Diagram Kadar protein Dalam tepung Kecambah Kacang Hijau}

Hasil penelitian menunjukkan bahwa tepung kecambah kacang hijau diperoleh kadar protein tertinggi sebesar $32,06 \% \mathrm{~b} / \mathrm{b}$, yaitu pada tepung kecambah yang dikecambahkan dengan menggunakan air kelapa. Hal ini disebabkan karena air kelapa memiliki banyak nutrisi yang berguna bagi proses perkecambahan seperti Kalium, gula, protein Natrium, kalsium, magnesium, ferum, cuprum, fosfor, sulfur, asam sitrat, asam nikotinat, asam pentotenal, asam folat, niacin, riboflavin, thiamin, serta memiliki beberapa hormon alami yang berguna bagi pertumbuhan kecambah yaitu auksin dan gibberilin [6].

Perendaman biji kacang hijau dalam kelapa dapat mengurangi waktu yang dibutuhkan biji tersebut untuk berkecambah karena adanya kandungan hormon pertumbuhan yaitu gibberellin pada air kelapa tersebut. Hal ini sesuai dengan pernyataan [17] bahwa peristiwa ini terjadi akibat adanya kandungan hormon gibberellin yang merupakan senyawa organik penting dalam proses perkecambahan karena dapat mengaktifkan reaksi enzimatik di dalam benih.

Sedangkan untuk tepung kecambah yang dikecambahkan dengan menggunakan Air Cucian Beras, kadar protein yang diperoleh yakni sebesar 31,19 \%b/b. Hal ini disebabkan karna Air Cucian Beras memiliki kandungan nutrisi yang berlimpah yaitu karbohidrat berupa pati, protein glutein, selulosa, hemiselulosa, gula dan vitamin yang tinggi. karena air cucian beras mempunyai kandungan karbohidrat yang tinggi. Karbohidrat bisa jadi perantara terbentuknya hormon auksin dan giberelin. Dua jenis bahan yang banyak digunakan dalam zat perangsang tumbuh (ZPT) buatan. Auksin bermanfaat untuk merangsang pertumbuhan pucuk dan kemunculan tunas baru sedangkan giberelin berguna untuk merangsang pertumbuhan akar.

\section{Kesimpulan}

Berdasarkan hasil penelitian yang dilakukan dapat dilihat bahwa dengan adanya penambahan media pada proses perkecambahan kacang hijau terdapat perbedaan kadar protein. Kadar protein pada tepung kecambah kacang hijau yang di kecambahakan dengan media air kelapa memiliki kadar rotein tertinggi yaitu $32,06 \%$, diikuti dengan tepung kecambah kacang hijau yang dikecambahkan dengan media air cucian beras $31,19 \%$ dan yang terendah adalah tepung kecambah kacang hijau yang dikecambahkan dengan media air $28,50 \%$

\section{Daftar Pustaka}

[1] Achyad, D.E. dan R. Rasyidah. 2006.http://www.asiamaya.com/jamu/isi/kacanghijauphaseolus radiatushtml.

[2] Ahdi, salim. 2011. Pengaruh Air Kelapa (Tua) Terhadap Tanaman Kacang Hijau. Proposal. Jambi. 
[3] Almatsier, sunita. 2001. Prinsip Dasar Ilmu Gizi. Gramedia pustaka utama. Jakarta

[4] Astawan, Made. 2011. Info Teknologi Pangan. Bogor Agricultural University.

[5] Auterhoff, H., \& Kovar, K.A. (2002). Identifikasi Obat. Bandung: Institut Teknologi Bandung

[6] Azwar. 2008. Air Kelapa Pemacu Pertumbuhan Anggrek. (online) web.ugm.ac.id. Akses : 14 Februari 2012.

[7] Fatmawaty. 2009. Kjeldahl. Makassar, Sulawesi Selatan.

[8] Fitriyasti, B. (2010). Kimia Organik. Padang: Universitas Baiturrahmah.

[9] G.M. Citra Wulandari, Muhartini, S., dan Trisnowati, S. 2012. Pengaruh Air Cucian Beras Merah dan Beras Putih Terhadap Pertumbuhan dan Hasil Selada (Lactuca sativa L.). Jurnal Vegetalica (online), 1(2).

[10] Kowara, sutrisno. 2012. Kacang-kacangan, Sumber serat yang kaya gizi. Artikel. Kusnandar, Feri. 2010. Kimia Pangan. Dian Rakyat. Jakarta

[11] Lehninger, A. L., 1982, Dasar-dasar Biokimia, Jlilid 1, Alih bahasa, Maggi Thenawijaya, Erlangga, Jakarta.

[12] Mustakim, M. 2014. Budidaya Kacang Hijau. Yogyakarta : Pustaka Baru Press.

[13] Nasrun, Elyana, Nina. 2011. Analisis kadar protein pada tepung Kecambah kacang hijau (phaseolus aureus l.) Dengan metode kjeldahl. Skripsi farmasi. Makassar

[14]Pamungkas, F. T., Darmanti, S., dan Raharjo, B. 2009. Pengaruh Kosentrasi dan Lama Perendaman Dalam Supernatan Kultur Bacilus Sp.2 DUCC-BR-KI. 3 Terhadap Petumbuhan Stek Horizontal Batang Jarak Pagarb(Jatropha curcas L.). (Online).b (http://eprints.undip.ac.id/2352/1/ Publikasi_Febri_JADI.pdf). 28 Oktober 2010

[15] Rukmana, Rahmat, 1997. Kacang Hijau Budi Daya Dan Pascapanen. Kanisius. Yogyakarta

[16] Sumantri, A.R. 2007. Analisis Makanan. Gadjah Mada University Press. Yogyakarta.

[17] Young, J, W,H. Ge, L. Ng, Y,F and Tan, N. 2009. The Chemical Composition and Biological Properties of Coconut (Cocos nucifera L.) Water. Natural Sciences and Sciences Education Group Nanyang Teknological University. Singapore. 